The Canadian Mineralogist

Vol. 38, pp. 713-715 (2000)

\title{
REFINEMENT OF THE STRUCTURE OF BANDYLITE
}

\author{
YAPING LI AND PETER C. BURNS ${ }^{\S}$ \\ Department of Civil Engineering and Geological Sciences, 156 Fitzpatrick Hall, University of Notre Dame, \\ Notre Dame, Indiana 46556-0767, U.S.A.
}

\begin{abstract}
The structure of bandylite, $\mathrm{Cu}_{2}\left[\mathrm{~B}(\mathrm{OH})_{4}\right]_{2} \mathrm{Cl}_{2}, Z=1$, tetragonal, $a$ 6.171(2), $c 5.587(3) \AA$, $V 212.7 \AA^{3}$, space group $P 4 / n$, has been refined by full-matrix least-squares techniques on the basis of $F^{2}$ using 263 unique reflections collected with MoKa $\mathrm{X}$-radiation and a CCD (charge-coupled device) area detector. The final agreement factor $(R 1)$ was $3.7 \%$ and the goodness-of-fit (S) was 0.90 for the 144 unique observed reflections $\left(\left|\mathrm{F}_{\mathrm{o}}\right|>4 \mathrm{~s}_{\mathrm{F}}\right)$. The structure consists of mixed-ligand Jahn-Teller-distorted $\mathrm{Cu}(\mathrm{OH})_{4} \mathrm{Cl}_{2}$ octahedra and $\mathrm{B}(\mathrm{OH})_{4}$ tetrahedra that are linked by vertex sharing.
\end{abstract}

Keywords: bandylite, borate, $\mathrm{Cu}$ oxysalt.

\section{SOMMAIRE}

Nous avons affiné la structure de la bandylite, $\mathrm{Cu}_{2}\left[\mathrm{~B}(\mathrm{OH})_{4}\right]_{2} \mathrm{Cl}_{2}, Z=1$, tétragonal, $a$ 6.171(2), c 5.587(3) $\AA$, V212.7 $\AA^{3}$, groupe spatial $P 4 / n$, par moindres carrés sur matrice entière sur la base de $F^{2}$ en utilisant 263 réflexions uniques prélevées avec rayonnement $\mathrm{MoK} \alpha$ et un détecteur à aire et à charges couplées $(\mathrm{CCD})$. Le résidu $R 1$ final est égal à 3.7\%, et l'indice de concordance $S$ est 0.90 pour 144 réflexions uniques observées $\left(\left|\mathrm{F}_{\mathrm{o}}\right|>4 \sigma_{\mathrm{F}}\right)$. La structure contient des octaèdres $\mathrm{Cu}(\mathrm{OH})_{4} \mathrm{Cl} l_{2}$, à ligands mixtes, rendus difformes à cause de l'effet Jahn-Teller, et des tétraèdres $\mathrm{B}(\mathrm{OH})_{4}$ articulés par partage de coins.

(Traduit par la Rédaction)

Mots-clés: bandylite, borate, oxysel de cuivre.

\section{INTRODUCTION}

Bandylite, $\mathrm{Cu}_{2}\left[\mathrm{~B}(\mathrm{OH})_{4}\right]_{2} \mathrm{Cl}_{2}$, is a rare $\mathrm{Cu}^{2+}$ borate that was first described from Mina Quetena, near Calama, Antofagasta, Chile by Palache \& Foshag (1938). Its structure was determined and refined by Collin (1951) using X-ray-diffraction data derived from film techniques. A modern structure refinement for bandylite has not been reported. We have refined the structure of bandylite and report the results herein.

\section{EXPERIMENTAL}

A specimen containing superb crystals of bandylite was provided by Dr. Mark Feinglos. A crystal with approximate dimensions $0.12 \times 0.06 \times 0.02 \mathrm{~mm}$ was selected for study. The crystal was mounted on a Bruker PLATFORM 3-circle goniometer equipped with a $1 \mathrm{~K}$ SMART CCD (charge-coupled device) detector with a crystal-to-detector distance of $5 \mathrm{~cm}$.

The data were collected using MoK $\alpha$ X-radiation. Preliminary examination of the diffraction pattern showed that the peak widths were $\sim 2^{\circ}$ in $\omega$, possibly indicating that the crystal was slightly bent. Owing to the fairly large peak-widths, frame widths of $0.6^{\circ}$ in $\omega$ were used for the collection of data, with $60 \mathrm{~s}$ used to acquire each frame. A sphere of three-dimensional data was acquired, and the data were analyzed to locate peaks for the determination of the unit-cell dimensions (Table 1), which were refined with 312 reflections using least-squares techniques. Data were collected for $3^{\circ} \leq 2 \theta \leq 56.6^{\circ}$ in approximately 22 hours; comparison of the intensities of identical reflections collected at different times during the data collection showed no decay. The three-dimensional data were reduced and corrected for Lorentz, polarization, and background effects using the Bruker program SAINT. A semiempirical absorption-correction was done on the basis of 196 intense reflections with the crystal modeled as an ellipsoid, which reduced $R_{\mathrm{INT}}$ from 5.3 to $4.8 \%$. A total of 1886 reflections were collected, of which there are 263 unique reflections with 144 classed as observed $\left(\left|F_{\mathrm{o}}\right| \geq 4 \sigma_{\mathrm{F}}\right)$.

§ E-mail address: pburns@nd.edu 
TABLE 1. MISCELLANEOUS INFORMATION FOR BANDYLITE

\begin{tabular}{|c|c|c|c|}
\hline $\begin{array}{l}a(\AA) \\
c(\AA)\end{array}$ & $\begin{array}{l}6.171(2) \\
5.587(3)\end{array}$ & Crystal size (mm) & $\begin{array}{l}0.12 \times 0.06 \\
\times 0.02\end{array}$ \\
\hline$V\left(\Lambda^{3}\right)$ & 212.7 & lotal ref. & 1886 \\
\hline Space group & $P 4 / n$ & Unique ref. & 263 \\
\hline$F(000)$ & 174 & Unique $\left|F_{0}\right| \geqslant 4 \sigma_{F}$ & 144 \\
\hline$\mu\left(\mathrm{mm}^{-1}\right)$ & 5.64 & Final $R$ & 3.7 \\
\hline$D_{\text {cale }}$ & 2.776 & $S$ & 0.90 \\
\hline \multicolumn{4}{|c|}{$\begin{array}{l}\text { Unit coll contents; } \mathrm{Cu}_{2}\left[\mathrm{~B}(\mathrm{OH})_{4}\right]_{2} \mathrm{Cl}_{2} \\
R 1-\Sigma\left(\left|\Gamma_{0}\right|-\left|\mathrm{F}_{i}\right|\right) / \Sigma \mathrm{F}_{\mathrm{d}} \mid\end{array}$} \\
\hline \multicolumn{4}{|c|}{$\begin{array}{l}S=\left[\sum w\left(\left|\mathrm{~F}_{\mathrm{s}}\right| \cdot\left|\mathrm{F}_{\mathrm{c}}\right|\right)^{2} /(m-n)\right]^{1 / 2}, \text { for } m \text { observations and } n \\
\text { parameters }\end{array}$} \\
\hline
\end{tabular}

\section{Structure Refinement}

Scattering curves for neutral atoms, together with anomalous dispersion corrections, were taken from International Tables for X-Ray Crystallography, Vol. IV (Ibers \& Hamilton 1974). The Bruker SHELXTL Version 5 system of programs was used for the refinement of the crystal structure.

Reflection statistics and systematic absences indicated space groups $P 4 / n$ and $P 4 / n m m$. Refinement of the structure was conducted in both space groups, proceeding from the structure model given by Collin (1951). In space group $P 4 / \mathrm{nmm}$, refinement of a model that included anisotropic-displacement parameters for all atoms converged to an agreement index $(R 1)$ of $9.0 \%$ calculated for the 144 observed reflections $\left(\left|F_{\mathrm{O}}\right| \geq 4 \sigma_{\mathrm{F}}\right)$. Inspection of the structure revealed that the $U_{11}$ displacement parameter for the $\mathrm{O}$ atom was unrealistically large, with a value of 0.19(2). In addition, the $\langle\mathrm{B}-\mathrm{O}\rangle$ bond length was found to be $1.44 \AA$, which is significantly smaller than normal. Refinement in space group $P 4 / n$ resulted in a substantial improvement in $R 1$, and it was possible to locate the $\mathrm{H}$ atom in difference-Fourier maps. The resulting anisotropic displacement parameters were found to be reasonable, with the $\langle\mathrm{B}-\mathrm{O}\rangle$ bond length equal to $1.477 \AA$, a typical value for borate tetrahedra. The refinement was done on the basis of $F^{2}$ using all 263 unique reflections, and included all atomic positional parameters with allowance for anisotropic displacement for all atoms except $\mathrm{H}$, and a weighting scheme of the structure factors. The refinement converged to a final agreement index $(R 1)$ of $3.6 \%$ calculated for the 144 unique observed reflections (the $R 1$ was $9.0 \%$ for all 263 unique reflections) and a goodness-of-fit $(S)$ of 0.90 . An isotropic correction for extinction was tried, but did not lead to an improvement of the refinement. Final atomic parameters are listed in Table 2. Observed and calculated structure-factors are available from the Depository of Unpublished Data, CISTI, National Research Council, Ottawa, Ontario K1A 0S2, Canada.

\section{Results}

The current study confirms the structure of bandylite presented by Collin (1951), although the precision of this refinement is much higher owing to the use of a modern detector of X-rays.

The single symmetrically distinct B atom is tetrahedrally coordinated by $\mathrm{OH}$ groups at a distance of 1.477(4) $\AA$. The tetrahedron bond-angles range from $108.5(3)$ to $109.9(2)^{\circ}$, with a $\langle\mathrm{O}-\mathrm{B}-\mathrm{O}\rangle$ angle of $109.47^{\circ}$.

The $\mathrm{Cu}^{2+}$ cation is coordinated by four $\mathrm{OH}$ groups and two $\mathrm{Cl}$ atoms, arranged such that the $\mathrm{OH}$ groups are located at the equatorial corners of a $(4+2)$-distorted octahedron. The $\mathrm{Cu}-\mathrm{OH}$ bond length is 1.966(3) $\AA$. There are two distinct $\mathrm{Cu}-\mathrm{Cl}$ bond-lengths, 2.732(4) and 2.854(4) ̊. Burns \& Hawthorne (1995) observed that this is the most common type of mixed-ligand $\mathrm{Cu}^{2+} \Phi_{6}$ octahedron $\left(\Phi: \mathrm{O}, \mathrm{OH}, \mathrm{H}_{2} \mathrm{O}\right.$ and at least one $\left.\mathrm{Cl}\right)$, and that it occurs in 12 mineral structures, including bandylite. Note that the mixed-ligand $\mathrm{Cu}^{2+} \Phi_{6}$ octahedron is strongly distorted owing to the Jahn-Teller effect. Expected $\mathrm{Cu}-\mathrm{OH}$ and $\mathrm{Cu}-\mathrm{Cl}$ bond-lengths in the absence of a distortion are 2.11 and $2.40 \AA$, respectively, on the basis of sums of ionic radii (Shannon 1976, Whittaker \& Muntus 1970). The Jahn-Teller distortion is responsible for a shortening of the equatorial $\mathrm{Cu}-\mathrm{OH}$ bonds by $0.14 \AA$, and a lengthening of the apical $\mathrm{Cu}-\mathrm{Cl}$ bonds by $\sim 0.4 \AA$.

The $\mathrm{H}$ atom refined to a position $0.86(5) \AA$ from the $\mathrm{O}$ position, and the $\mathrm{H}$ bond is accepted by a $\mathrm{Cl}$ atom with a $\mathrm{H} . . . \mathrm{Cl}$ bond length of $2.39(5) \AA$ and a $\mathrm{O}-\mathrm{H} . . . \mathrm{Cl}$ bond angle of $153.9^{\circ}$. Each $\mathrm{Cl}$ atom is bonded to two $\mathrm{Cu}^{2+}$ cations and accepts four $\mathrm{H}$ bonds.

Various views of the structure are presented in Figure 1. The structure consists of layers of $\mathrm{Cu}^{2+} \Phi_{6}$ octahedra and $\mathrm{BO}_{4}$ tetrahedra that are parallel to (001),

TABLE 2. FINAL ATOMIC PARAMETERS FOR BANDYLITE

\begin{tabular}{lcccccccccc}
\hline & $x$ & $y$ & $z$ & ${ }^{*} U_{\text {业 }}$ & ${ }^{*} U_{11}$ & $U_{22}$ & $U_{33}$ & $U_{12}$ & $U_{13}$ & $U_{23}$ \\
\hline $\mathrm{Cu}$ & 0 & $1 / 2$ & $0.6317(4)$ & $139(5)$ & $86(5)$ & $86(5)$ & $245(10)$ & 0 & 0 & 0 \\
$\mathrm{Cl}$ & 0 & $1 / 2$ & $0.1427(6)$ & $187(7)$ & $182(10)$ & $182(10)$ & $195(19)$ & 0 & 0 & 0 \\
$\mathrm{~B}$ & 0 & 0 & $1 / 2$ & $166(31)$ & $52(39)$ & $52(39)$ & $396(86)$ & 0 & 0 & 0 \\
$\mathrm{O}$ & $0.3134(5)$ & $0.5540(5)$ & $0.6543(8)$ & $122(9)$ & $78(18)$ & $102(18)$ & $186(26)$ & $-8(14)$ & $-26(19)$ & $-32(19)$ \\
$\mathrm{H}$ & $0.155(9)$ & $0.150(9)$ & $0.753(9)$ & 200 & & & & & &
\end{tabular}



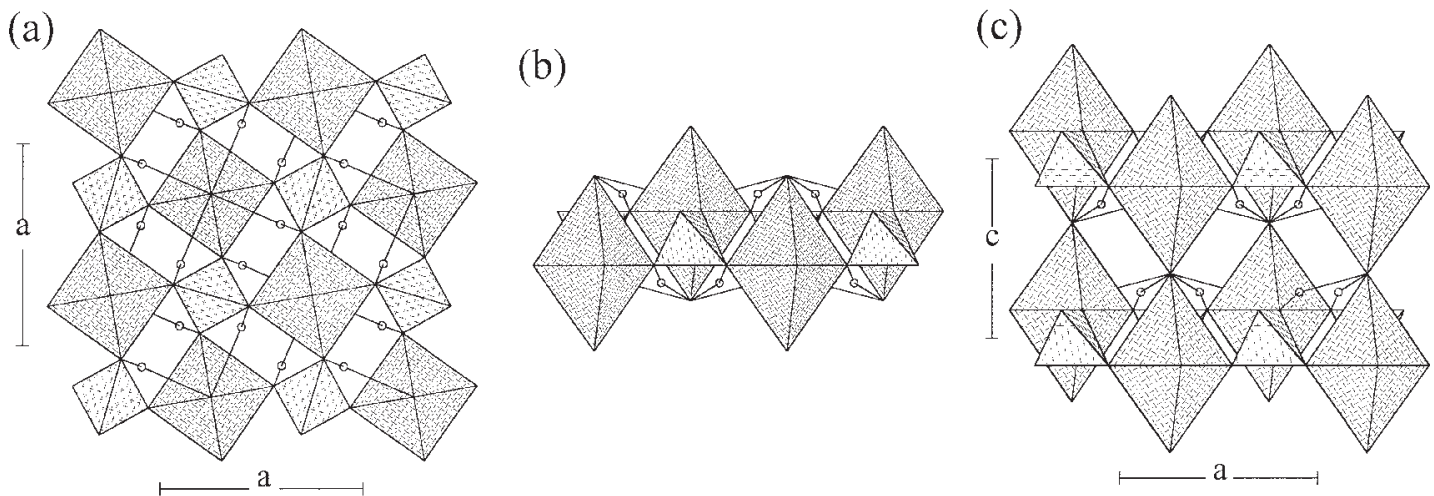

FIG. 1. Polyhedral representations of the structure of bandylite (a) projected along [001], (b) layer projected along [010], and (c) projected along [010]. $\mathrm{B}(\mathrm{OH})_{4}$ tetrahedra are shaded with crosses, and $\mathrm{Cu}(\mathrm{OH})_{4} \mathrm{Cl}_{2}$ octahedra are shaded with a herring-bone pattern. $\mathrm{H}$ atoms are represented by open circles, with lines illustrating the $\mathrm{H}$ bonds.

arranged such that each tetrahedron shares all of its vertices with $\mathrm{Cu}^{2+} \Phi_{6}$ octahedra (Fig. 1a). $\mathrm{H}$ bonds extend from the shared vertices to $\mathrm{Cl}$ atoms located at the apical positions of adjacent $\mathrm{Cu}^{2+} \Phi_{6}$ octahedra. Only one half of the $\mathrm{Cl}$ atoms receive $\mathrm{H}$ bonds from within the layer; the remaining receive $\mathrm{H}$ bonds from an adjacent symmetrically identical layer (Fig. 1b). Adjacent layers are linked by the sharing of $\mathrm{Cl}$ atoms at the apical positions of $\mathrm{Cu}^{2+} \Phi_{6}$ octahedra, and by $\mathrm{H}$ bonds (Fig. 1c). The $\mathrm{B}(\mathrm{OH})_{4}$ tetrahedra are not polymerized, thus representation of the fundamental building block in bandylite is $1 \square: \square$ (Burns et al. 1995).

The structure of bandylite is confirmed to be in space group $P 4 / n$, as earlier reported by Collin (1951). The structure approximately conforms to space group $P 4 / \mathrm{nmm}$, as can be seen in Figure 1a. Relatively small rotations of the $\mathrm{BO}_{4}$ tetrahedra would bring the structure into conformation with $P 4 / \mathrm{nmm}$, but would diminish the strength of the $\mathrm{H}$ bonds donated by the hydroxyl groups of the borate tetrahedra, and accepted by the $\mathrm{Cl}$ anions in the apical positions of the $\mathrm{Cu}^{2+} \Phi_{6}$ octahedra.

\section{ACKNOWLEDGEMENTS}

We thank Dr. Mark Feinglos for providing the crystals used in this study. The manuscript was significantly improved following careful and detailed reviews by Dr. Joel Grice and Mr. Mark Cooper. We thank Dr. Robert F. Martin for his editorial suggestions.

\section{REFERENCES}

Burns, P.C., Grice, J.D. \& Hawthorne, F.C. (1995): Borate minerals. I. Polyhedral clusters and fundamental building blocks. Can. Mineral. 33, 1131-1151.

\& Hawthorne, F.C. (1995): Mixed-ligand $\mathrm{Cu}^{2+} \Phi_{6}$ octahedra in minerals: observed stereochemistry and Hartree-Fock calculations. Can. Mineral. 33, 1177-1188.

Collin, R.L. (1951): The crystal structure of bandylite, $\mathrm{CuCl}_{2} \bullet \mathrm{CuB}_{2} \mathrm{O}_{4} \bullet 4 \mathrm{H}_{2} \mathrm{O}$. Acta Crystallogr. 4, 204-209.

Ibers, J.A. \& Hamilton, W.C., eds. (1974): International Tables for X-ray Crystallography. IV. The Kynoch Press, Birmingham, U.K.

Palache, C. \& Foshag, W.F. (1938): Antofagasite and bandylite, two new copper minerals from Chile. Am. Mineral. 23, 85-90.

Shannon, R.D. (1976): Revised effective ionic radii and systematic studies of interatomic distances in halides and chalcogenides. Acta Crystallogr. A32, 751-767.

WhitTAKeR, E.J.W. \& MunTus, R. (1970): Ionic radii for use in geochemistry. Geochim. Cosmochim. Acta 34, 945-956.

Received January 10, 2000, revised manuscript accepted May 2, 2000. 
